\title{
The Analysis and Consideration to Talents Training In Higher Vocational Colleges of Professional Skills Competition
}

\author{
Yan Zhu' ${ }^{1, a}$, Jiao Feng ${ }^{1, b}$, Shuang gao ${ }^{1, c}$, Jie Zhang ${ }^{1, d}$, Lihua Sun ${ }^{1, \text { e }}$, \\ Chun Tang ${ }^{1, f}$ \\ ${ }^{1}$ Liaoning economic management cadre Institute, Liaoning 110122, China; \\ a46581081@qq.com, b8820331@qq.com, c35681729@qq.com, d23096984@qq.com, \\ e21521615@qq.com, '2296081639@qq.com
}

Keywords: Professional skills competition; talent training; professional quality; evaluation system; course reform; integration of teaching.

\begin{abstract}
The important indicator of higher vocational education personnel training is the level of professional skills and practical ability. However, the phenomenon that takes theory seriously and despises the practice of Chinese higher vocational talent training is still widespread. In this paper, with the development of vocational skills competition, the talent training goal that was suitable for Industry needs was further cleared. It performs the work process oriented reform for the existing curriculum system and thus makes teaching to connect with professional post and professional qualification. Furthermore, it promotes the communication between different higher vocational colleges and also provides a platform for the promotion of teachers' practical skills. Professional skills competition reflects the latest needs of high skilled talents in the industry and enterprises. Therefore, the sustainable development of higher vocational education in our country was realized. Practice proves that the player of skills competition training has advantage in the employment competitiveness and the sustainable development ability.
\end{abstract}

\section{Introduction}

On the basis of the national vocational skills standard, professional skills competition can highlight operation skill and solving actual problem. Professional skills competition can cultivate students' innovation consciousness, practical ability, aggressive spirit and the team consciousness. Seamless joint could also be advanced between vocational college and industry. Educational reform was promoted and the comprehensive quality of students was also cultivated with attending professional skills competition. Competition results could be promoted and the connotation of technology innovation could be enriched by results of the educational reform. Three-dimensional mode of talent training was built; high-quality talents with a reasonable knowledge structure, basic work consciousness, high technical skills and strong innovation capability were trained.

It is clearly put forward by national medium and long-term education reform and development plan that students' vocational skills, professional ethics, employment entrepreneurship quality and the senior applied talents with certain theoretical basis and practical ability should cultivate by educational work in higher vocational colleges[1]. Therefore, professional skills and practical ability were important indexes to judge the comprehensive quality of college students. The characteristics of innovation model must be highlighted by teaching practice in higher vocational colleges. Professional skills competition was the important achievements of the reform and development in higher vocational education. It played an important guiding role and reference value in rational evaluation and selection of the current applied talents with high quality. Now it becomes the important carrier of cultivating skilled talents in higher vocational colleges. It is worthy for further research and discussion as well. 


\section{The Analysis of Higher Vocational Talents Training Effect Based from the Perspective of Professional Skills Competition.}

\subsection{Define talents training goal further.}

In China, compared with basic education and undergraduate education, higher vocational education starts later, but it develops quickly. So the development of its education theory lagged behind the practice[2]. A phenomenon in emphasizing theory and neglecting practice is existed in numbers of our higher vocational colleges. The training target of higher vocational talents was positioned in high-skilled talents. The vocational ability was cultivated as the main line in higher vocational colleges. The talents training goal of higher vocational had been defined further and high-skilled talents for the industry and society had been cultivated by professional skills competition.

\subsection{Promote the reform of the existing curriculum system.}

The forefront and developing trend of the industry and social was usually reflected by professional skills competition items. They also reflected the industry's latest vocational skills and the urgent demands of practical high skilled talents. At the same time, the setting of professional skills competition items and competition standards also greatly enriched the connotation of professional teaching. The competition process played a demonstrative teaching role[3]. According to the requirements of professional skills competition to vocational skills, learning content were divided by the working process, declarative knowledge and procedural knowledge was integrated, theory and practice of knowledge was also integrated and professional curriculum system which is oriented by working process was established.

For example, according to the set of skills competition item, many colleges expanded practice course of "identification of traditional Chinese medicine". In addition to the theoretical part of the classroom teaching, it also provided opportunities for students to practice in training base in school so thus improve the teaching efficiency.

\subsection{Promote the integration of teaching content.}

At present, the competitive system of professional skills competition has built relatively complete. Three-level competition of nations, provinces (ministries) and cities (schools) was formed. The competition could meet the needs of different levels and different grade students in higher vocational colleges[4]. In order to further improve the pertinence of skilled talents training, the existing teaching system should be optimized and adjusted by higher vocational colleges. Moreover, the professional skills competition and classroom teaching should be adapted each other. We built the teaching atmosphere combining education with competition contents. Students' professional skills were cultivated hierarchically. The competitive item could be taken as a carrier of teaching by higher vocational teachers. The theoretical knowledge, practical skills, creative thinking and professional quality what student should master in professional skills competition could be carried out in class[5]. The professional teaching in higher vocational colleges and professional skills competition could be effectively adapted each other. The professional teaching could be connected with professional post, so did professional and technical standards with professional qualification certification. The objective of skilled talents training would be realized in vocational colleges beneficially.

With reference to the industry standard, teaching content should be regrouped. The areas of action which provide the service translated into the major area of study. The disjointed phenomenon between the teaching content and actual requirements was been solved. The course content was connected with professional standards.

For example, many vocational colleges which establish traditional Chinese medicine major joined the course named "traditional Chinese medicine dispensing" into teaching program after attending national vocational traditional Chinese medicine skills competition. "Traditional Chinese medicine dispensing" is a course which improves identification and dispensing of traditional Chinese medicine. It can promote dispensing speed and accuracy of Chinese medicinal formulae. Students must master this skill when they work in dispensary of traditional Chinese medicine or pharmacy of traditional Chinese medicine. As a result, according to the need of cultivating high-skilled talent, vocational colleges teach theoretical knowledge with "essential” and "sufficient” as a standard. On the basis of 
professional skills competition, industries and enterprises became to the new subject of course system construction. Students could qualify the needs of practical work after graduation.

\subsection{Promote the construction of talent training evaluation system.}

Through the skills competition, higher vocational colleges' level of talent training could be analyzed from one side by its own competing scores. In order to test their own teaching level and effect, the skills competition should take as the carrier by higher vocational colleges. The construction of talent training evaluation system should be promoted to build. In addition, the internal mechanism of teaching supervision and inspection in school should be established, intercollegiate results' comparison should be also established by vocational colleges in time[6]. The insufficiency could be found by comparing with others, the direction and method of talent training could be adjusted in time. For example, interscholastic communications were carried out by many higher vocational colleges which came from the same region and even same across. Furthermore, a talent training quality information feedback system had established, so did the teaching quality monitoring system, etc.

\subsection{Promote the construction and cultivation of "double type" teaching staff}

The conduct of professional skills competition was an important way of promoting the students to improve their skills. Moreover, higher vocational teachers had also strengthened their teaching communication. A good platform was provided to improve the quality of the skills[7]. Before the conduct of professional skills competition, teachers usually provided professional counseling and competition guidance to the participants. Teachers' professional theory knowledge could be consolidated in the process, they could find insufficient on their knowledge structure and teaching ability in time. Self-reflection and active learning could be carried out easily. Their professional qualities and educational skills could be constantly improved. Furthermore, with the help of this communication platform of professional skills competition, the teaching and training activities could be widely carried out by teachers from different colleges; mutual learning from each other was achieved. All sorts of problems existing in the teaching and scientific research work were corrected timely. More effective education strategy was found together. In the process of competition, many new theories, new technology and new equipment often has been come into be contacted with and education vision of higher vocational teacher was opened. To be a certain extent, the construction of double type teachers had promoted by the competition in higher vocational colleges[8].

In professional skills competition, the student's performance had also reflected the level of graduate teachers from one side. The teachers' practical operating skills would improve based on professional skills competition, by inviting experts of industries and enterprises to participate in the preparation process of skills competition. Teachers and students had trained together by experts. The practical operation skills of teachers also improved with attending the skills competition.

\section{Reflections and Suggestions about the Current Information on the Development of Professional Skills Competition.}

Professional skills competition starts late in china. However certain achievement has been obtained in the short term, with holding professional skills competition more often. Many problems of actual operation and institutional improvement were exposed gradually, especially in the competition of province and city level. The competition process was lack of openness and fairness, even with negative effects that were discovered such as replacing exam or training with competition[9]. There was an urgent need that the specification and guidance of professional skills competition should be strengthened by relevant departments, in order to take its advantages in skilled talents training.

\subsection{Objective location of vocational skills competition.}

The purpose of carrying out professional skills competition is training outstanding talent of higher professional quality and professional skills, not to let students take honor certificate. But in order to be famous through professional skills competition, some higher vocational colleges or students even expensed the normal learning time of students. The wrong competition location was not compatible with the original intention of holding professional skills competition obviously. It's difficult for 
professional skills competition to play its role in cultivation of students, construction of practical training, course construction, etc. The long-term development of students was gone against.

\subsection{Build a scientific mechanism of professional skills competition.}

In order to realize the healthy and sustainable development of professional skills competition, high-level education department must attach importance to the top-level design of competition. On the basis of foreign advanced experience, a professional skills competition mechanism had been built. It is fit for national condition in China and the characteristics of vocational education. According to major setting and course characteristics of higher vocational colleges, management system and measures for the implementation of professional skills competition were detailed formulated. Then, the level of professional skills competition could improve constantly [10].

\subsection{Do not ignore the cultivation of students' professional knowledge and professional norms awareness.}

All professional technology and process are constantly developing and changing. Therefore, the holding of professional skills competition was not the end of the students' learning. Students had obtained certain professional skills and good habit of active thinking and self-learning should be developed. Good professional norms awareness should be developed in the process so that students can benefit for all their life.

\section{Conclusion}

Professional skills competition as a new thing, its meaning has no event itself, but more on promotion of higher vocational colleges training. A kind of promoting development of "forced" mechanism was formed for higher vocational education talent training by professional skills competition. Vocational education had promoted the development of persisting with the guide of competition. The nature of vocational education features had been leaded returning. Thus we could realize the sustainable development of higher vocational education.

Professional skills competition reflected the latest demand for high-skilled talents in the industries and enterprises in every level. The latest development of industries and enterprises for skills required was also reflected. Therefore, according to their own actual situation, the higher vocational colleges should participate in the professional skills competition actively. As an opportunity, higher vocational talents training mode continuously explored and researched. High-skilled talents who conformed to the industries and enterprises practical demand were cultivated. Therefore, the sustainable development of higher vocational education in our country was realized. Practice proves that the player of skills competition training has advantage in the employment competitiveness and the sustainable development ability. They also were popular with employers.

\section{References}

[1]. Mingliang Liang, and Huimin Zhang, "National higher vocational students' skills competition on the promotion of teaching reform and talent training," Experimental Technology And Management, vol. 28, pp. 161-163, February 2011 (In Chinese).

[2]. Yongxin Liu, and Xuesen Du, “The relationship between professional skills competition and higher vocational talents training mode,” Education and Vocation, vol. 21, pp. 43-44, July 2014 (In Chinese).

[3]. Wenjuan Liu, Yanli Li, and Zhen Lin, etc, "Influence of professional skills competition on the talent training mode of pharmacy professionals,” China Pharmacy, vol. 25, pp. 478-450, February 2014 (In Chinese).

[4]. Zhili Wu,“Vocational skills competition countermeasures analysis of skilled personnel training in higher vocational colleges," Communication of Vocational Education, vol. 26, pp. 25-27, 2013 (In Chinese). 
[5]. Jiaoming Li, "The current situation and thinking of students professional skills competition," Adult Education, vol. 11, pp. 41-42, 2010 (In Chinese).

[6]. Zhixian Meng, “Skills competition in vocational education,” Journal of Tianjin Vocational Institutes, vol. 13, pp. 3-10, April 2011 (In Chinese).

[7]. Amin Zhang, and Dazhen $\mathrm{Xu}$,“ The current situation analysis and countermeasure research of national vocational students skills competition,” Higher Vocational Education-Journal of Tianjin Vocational Institute, vol. 22, pp. 13-15, October 2013 (In Chinese).

[8]. Jing Mi, Modern Vocationalism. Tianjin university press, 2010, pp.68-73 (In Chinese).

[9]. Zhaoxu Li, "The promotion of professional skills competition to vocational education curriculum reform,” Journal of Qingyuan Polytechnic, vol. 2, pp. 115-118, 2009 (In Chinese).

[10]. Binghe Chen, "Research on the value of skills competition to higher vocational talents training,” Chinese Vocational and Technical Education, vol. 9, pp. 36-37, March 2008 (In Chinese). 